\title{
The Correlation Between Grammatical Competence, Vocabulary Mastery, And Translating Skill
}

\author{
Muhammad Hamam Abdurrohman, Ahmad Dahlan Rais, Dewi Sri Wahyuni \\ English Education Department \\ Sebelas Maret University \\ Surakarta \\ Email: muhhamam1992@gmail.com
}

\begin{abstract}
This research purposes are to know whether the vocabulary mastery and grammatical competence affect translating and shows how much vocabulary mastery and grammatical competence affect translating skill. The research population was the eleventh grade of SMA N 1 Wonosari in 2013/2014 academic year which consisted of eight classes with 320 students in total. The research sample was 36 students in a single class. The sample was chosen with cluster random sampling technique. The method used to acquire the data is by using test to the one class selected as sample in the school. The data analyzed by correlational method. The result shows that grammatical competence and vocabulary mastery affect translating skill and significantly influence the translating skill $(\mathrm{Fo}=10.82>\mathrm{Ft}$ 3.32). The result of this research also shows that grammatical competence and vocabulary mastery are important factors that give contribution to translating skill with $45.59 \%$ contribution value.
\end{abstract}

Keywords: grammatical competence, vocabulary mastery, translating skill.

\begin{abstract}
Abstrak
Tujuan penelitian ini adalah untuk mengetahui antara penguasaan kosakata dan kompetensi gramatikal mempengaruhi kemampuan menerjemahkan dan menunjukan seberapa besar pengaruhnya terhadap kemampuan menerjemahkan. Populasi penelitian adalah kelas 11 di SMA N 1 Wonosari tahun pelajaran 2013/2014 yang terdiri dari 8 kelas dengan jumlah 320 siswa. Sampel penelitian adalah 36 siswa dalam satu kelas. Sampel dipilih dengan menggunakan teknik kluster acak. Metode pengambilan data dengan menggunakan tes pada kelas yang terpilih sebagai sampel. Data dianalisa menggunakan metode korelasi. Hasil penghitungan menunjukan bahwa kompetensi gramatikal dan penguasaan kosakata secara signifikan mempengaruhi kemampuan menerjemahkan (Fo = 10.82 > Ft 3.32). Hasil dari penelitian ini juga menunjukan bahwa kompetensi gramatikal dan penguasaan kosakata adalah faktor penting yang member kontribusi pada kemampuan menerjemahkan dengan nilai kontribusi 45.59\%
\end{abstract}

Kata Kunci: kompetensi gramatikal, penguasaan kosakata, kemampuan menerjemahkan. 
It is not argued that English nowadays is studied in EFL countries. Indonesian EFL learners require translation ability because English is a foreign language to them. Differences in grammar system and vocabulary between Indonesian and English become a challenge for EFL learners in translating English to Indonesian and vice versa. Technology advancement also demands EFL learners to understand English besides its importance in education and competition in job market. EFL learners who study advanced education such as university require English skill as many university books are written in English for all disciplines and students also come from abroad.

In order to communicate in different languages, translating skill is needed. Translation skill is important to communicate in different languages in all aspect of daily life, education, and workplace. Communication between different languages leads to exchanging knowledge, cultures, and information. The variety of languages with different cultures and necessity of communications in human life caused translation to be a very effective factor in communicating, exchanging cultures, and knowledge (Abbasi, 2012:1).

Ability to translate will be useful in academy and workplace. In academy, students especially EFL learners will run into foreigner or English books. In the advanced or final stage of language teaching, translation from L1 to L2 and L2 to L1 is recognised as the fifth skill and the most important social skill since it promotes communication and understanding between strangers (Newmark, 1991:92). 
In workplace, a professional translator requires high degree of language skill, knowledge, and experience. Translators do more than simply translate words - they relay concepts and ideas between languages. They must thoroughly understand the subject matters in which they work so they are able to convert information from one language, known as the source language, into another, the target language (Jones, 2002:22)

With differences in English and Indonesian grammar and vocabulary, translating skill is required to be able to understand foreign language. Translating becomes difficult when a student does not have ability or knowledge in some supporting aspects such as grammatical competence and vocabulary mastery. Lacking any of those aspects may lead into mistranslation and misperceive which influences translation quality.

After considering the influences of grammar and vocabulary toward translating skill, the researcher determined the following hypotheses 1) there is a positive correlation between grammatical competence and translating ability of the Eleventh Grade of Students of SMA N 1 Wonosari in the 2013/2014 Academic Year, 2) there is a positive correlation between vocabulary mastery and translating ability, 3) there is a positive correlation between grammatical competence, vocabulary mastery, and translating ability. 


\section{RESEARCH METHODS}

This research is aimed to prove the proposed hypotheses along the significance level and which aspect either grammar or vocabulary affects more to the translating skill.

This research used correlational method in order to know the connection or relationship between two or more variables. It also shows the relation strength between variables. Santrock (2011:18) states that correlational method is a method which has a goal of describing the strength of the relation between two or more events or characteristics. He also states that the correlational method is useful because the stronger two events are correlated (related, or associated), the more effective we can predict one from the other.

The population is 320 students in eleventh grade in SMA N 1 Wonosari at 2013-2014 academic year which are divided into 8 classes. One class selected as the test sample. A sample in a research study is the group on which information is obtained (Fraenkel, Wallen, and Hyun, 2012:91). The sample was selected by cluster random sampling. Cluster random sampling is selection of groups, or clusters, of subjects rather than individuals (Fraenkel, Wallen, and Hyun, 2012:95). The sample selection is randomly choose among 8 classes so each classes has $12.5 \%$ chance of being selected. The $N$ for the sample was class A3.

The research used test as the technique to collect the data for the research. The test is used to collect the data of student's grammatical competence, vocabulary mastery and student's translation skill. The test question is in form of 
multiple choices with four answers given (A, B, C, and D). The number of question for grammatical competence, vocabulary mastery, and translating skill is various for each subject. Grammatical competence test contains 35 questions. Vocabulary mastery test contains 33 questions. Translating skill items contains 30 questions.

In order to acquire accurate data, validity and reliability test have been carried out to test the data in the research. Validity is the extent to which result can be interpreted accurately and reliability refers to the consistency of the research and the extent to which studies can be replicated (Wiersma, 2000:6) Biserial Correlation Formula has been used in measuring the validity of the grammatical competence, vocabulary mastery and translation skill and to measure the reliability of the grammatical competence, vocabulary mastery, and translating skill the writer uses Kuder Richardson-20 (KR-20) formula.

After acquiring accurate data, various tests have been carried out such as normality test, regression test, single correlation, and multiple correlation test. Normality test is used to know whether the data are in normal distribution. Regression test is used to know whether two variables have significant linear regression or not. Single and multiple correlations are used to test the purposed hypotheses in this research.

\section{RESEARCH FINDINGS}

From the data analyzed in the research, it is found that the correlation value of grammatical competence $(\mathrm{X} 1)$ and translating skill $(\mathrm{Y})\left(\mathrm{r}_{\mathrm{x} 1 \mathrm{y}}\right)$ is 0.54 , the 
correlation value vocabulary mastery $\left(\mathrm{X}_{2}\right)$ and translating skill $(\mathrm{Y})\left(\mathrm{r}_{\mathrm{x} 2 \mathrm{y}}\right)$ is 0.407 , and the correlation value grammatical competence $\left(\mathrm{X}_{1}\right)$ and vocabulary mastery $\left(\mathrm{X}_{2}\right)$ simultaneously and translating skill $(\mathrm{Y})\left(\mathrm{r}_{\mathrm{x} 12 \mathrm{y}}\right)$ is 0.629 . All values are above the significance level $\mathrm{r}$ table ( $\mathrm{r}_{\text {table }}$ for $\alpha=0.05$ for $\mathrm{N}=36$ which is $0.329\left(\mathrm{r}_{\mathrm{x} 1 \mathrm{y}}>\right.$ $\left.r_{\text {table }}, r_{x 2 y}>r_{\text {table }}, r_{x 12 y}>r_{\text {table }}\right)$. This means all proposed hypotheses are proven correct based on the data calculation.

After the proposed hypotheses are proved, it is also found that both grammatical competence and vocabulary mastery are significantly affect the outcome of translating skill. The significance value of grammatical competence toward translating skill is 3.7 and as for vocabulary mastery toward translating skill is 2.6. Then both values are consulted to $t_{\text {table }}$ with 1.7 value. It can be seen that both significance values exceed the $t_{\text {table }}$ values. It means that those values are significant.

The research shows that $45.59 \%$ of the translating skill is influenced by grammatical competence and translating skill and the rest are affected by other factors. Grammatical competence contributed $26.49 \%$ and vocabulary mastery contributed $19.10 \%$ toward translating skill from the total influence value

\section{DISCUSSION}

It shows that almost half of the translating skill (45.59\%) influenced by grammatical competence and vocabulary mastery. It implies that grammatical competence and vocabulary mastery are important toward translating skill. It makes sense that students with good grammatical competence will be easier to 
understand the text and able to write text in a good and correct sentences. Grammar itself is viewed as an essential element for communication to take place because it shows how language is used (Ismail, 2010:143).

A positive and significant correlation between grammatical competence and translating skill means the more grammatical competence a student have, he/she will have better translating skill. Grammatical rules, being just the organizers of words, which is considered as the foundation of a language, are quite important during the process of translating (Shi, 2014:875).

This applies to vocabulary mastery too. Vocabulary is an important aspect in language learning. Vocabulary is central to language and of critical importance to the typical language learner (Coady and Huckin, 1997:4). By knowing the meaning of a word, students will know the word meaning in another language and will help the students to translate a text. Learning vocabulary is a part of learning any language, one should think that way to achieve that goal (Taheri, 2014:545).

With more than $50 \%$ other aspects beside grammatical competence and vocabulary mastery which is influences translating skill, it is advised to other researchers to investigate other factors that influence the translating skill. There are other possible factors such as intelligence, motivation to read and writing, cultural knowledge, and motivation to learn another language, and many more which have not yet investigated in this research. 


\section{CONCLUSION}

From the research result and data calculation, the drawn hypotheses are proven true. It indicates that the increase of grammatical competence and vocabulary mastery either separately or simultaneously will be followed by the increase of translating skill and vice versa.

As there is also a positive and significant correlation between vocabulary mastery and translating skill, there will be an increase of translating skill if a student have more vocabulary mastery and vice versa. Vocabulary is very important in learning any language and very important skill in translation.

The result also indicates that grammatical competence and vocabulary mastery have a significant contribution toward translating skill, which means that grammatical competence and vocabulary mastery are an important factor to improve translating skill.

It is suggested that in order to improve translating skill, it is advised to improve the grammatical competence and vocabulary mastery because it has been proven affected the translating skill. Teacher should aid the students' grammatical competence so the students will have their translating skills improved. Students themselves can improve vocabulary mastery through reading books. 


\section{BIBLIOGRAPHY}

Abbasi, G., Saleh, S., Janfaza, E., Assemi, A., Dehghan, S. (2012). Language, Translation, and Culture. International Conference on Language, Medias and Culture, (33). 83-87. Retrieved 17 March 2014, from http://ipder.com/icc/upload/journals/2012/vol33/article/.pdf.

Coady, J., Huckin, T. (1997). Second Language Vocabulary Acqusition: a Rationale for Pedagogy. USA: Cambridge University Press.

Fraenkel, J. R., Wallen, N. E., Hyun, H. H. (2012). How to Design and Evaluate Research in Education. New York: McGraw-Hill.

Ismail, S. (2010). ESP Students' Views Of ESL Grammar Learning. GEMA Online TM Journal of Language Studies. 10(3). 143-156. Retrieved 11 April 2014, from http://gemaonline.com/jls/ issue3/2010/ article/12.pdf.

Jones, E. (2002). Interpreter and Translators. Occupational Outlook Quarterly. 46(2). 23-29. Retrieved 11 April 2014, from www.literarytranslators.org /2010/summer/article/jones.pdf.

Newmark, P. (1991). About Translation. USA: Multilingual Matters.

Santrock, J. (2011). Educational Psychology. New York: McGraw-Hill.

Shi, X. (2014). Chinese-English Translation Strategies of Public Signs Based on Functional Equivalence Theory. Journal of Language Teaching and Research. 5(4), 873-877. Retrieved 24 August 2014, from http://jltr.com/journals/article/54.pdf.

Siddiek, A. G. (2010). The Impact of Test Content Validity on Language Teaching and Learning. Asian Social Science. 6(12). 133-143. Retrieved 4 April 2014, from www.ccsenet.org/ass/issue-12/vol-6/12.pdf. 
Taheri, M. (2014). The Effect of Using Language Games on Vocabulary Retention of Iranian Elementary EFL Learners. Journal of Language Teaching and Research. 5(3), 544-549. Retrieved 24 August 2014, from http://jltr.com/journals/article/53.pdf.

Wiersma, William. 2000. Research Methods in Education: an Introduction. USA: Allyn \& Bacon. 